\title{
Forgery: Legislation Gone Mad or Legitimate Social Threat?
}

\section{Carissa Hamoen}

Forgery in eighteenth-century London was more than a crime of opportunity; it completely undermined the economic, social and political orders of that society. Using the works of authors such as Randall McGowen, John Beattie, Craig Muldrew, and others, this paper examines cases tried in the London Old Bailey from 17001740 in the context of the financial revolution and the rise of the bloody code. The paper looks at the implications this crime had on the greater London society, the changes in legislation that came about as a result of forgery, and the changes in punishment for the crime. Ultimately, it examines at the reasons for the radical change in people's perception of this crime in such a short time period.

In 1728 a sensational forgery case created headlines all around Britain. William Hales, a respected goldsmith, was convicted for forging several promissory notes that cost some very important people, including several parliamentarians, thousands of pounds. This case was punished in the usual way-Hales was pilloried, fined, and imprisoned. ${ }^{1}$ To the people of London, the magnitude of his crime deserved a more severe punishment; many thought he should have received the death penalty. Ironically, they got their wish when Hales died in prison, probably of gaol fever. ${ }^{2}$ This case highlighted the vulnerabilities of Britain's newly formed paper based credit system and economy. The changes brought about by the financial revolution in Britain under William of Orange and the Hanoverian monarchs made forgery easier to commit and disguise. As a result, in 1729 a forgery statute was presented and passed by Parliament, declaring that anyone caught forging

any Deed, Will, Testament, Bond, Writing-Obligatory, Bill of Exchange, promissory Note for Payment of Money, Indorsement or Assignment of any Bill of Exchange, or promissory Note for Payment of Money, or any Acquittance or Receipt, either for Money or Goods... with intention to defraud any Person whatsoever, knowing the same to be false, forged, or counterfeited every such Person, being thereof lawfully convicted, shall be deemed guilty of Felony, and suffer Death as a Felon, without Benefit of Clergy... ${ }^{3}$

By the third decade of the eighteenth century, forgery was viewed as more than just a crime of opportunity; it undermined the entire economic and monetary system, and threatened to return Britain to the disorder that had characterized the Stuart monarchy.

Eighteenth-century Britain was obsessed with creating and maintaining order by means of the law. This was due in part to past political circumstances: the civil war, the Restoration and the Glorious Revolution were all very fresh in the minds of eighteenth-century British people. Under William of Orange and his descendants, thousands of statutes were passed by Parliament in an attempt to restore order to the country. Even with these new statutes in place, the crime of forgery was given very little attention until the early eighteenth century, coinciding with Britain's Glorious Revolution.

\footnotetext{
${ }^{1}$ McGowen, Randall. "From Pillory to Gallows: The Punishment of Forgery in the Age of the Financial Revolution" in Past \& Present 165, Nov. 1999 (107-1740), 123-124.

2 Ibid., 124

${ }^{3}$ Old Bailey Proceedings Online (accessed March 24, 2011), October 1733, trial of Edmond Bourke (t-17331010-21).
} 
The Glorious Revolution followed a period of disorder, in which neighbours were fighting neighbours, a king was deposed and executed, and the government tried to rid the country of absolute monarchy. When the Hanoverian kings came to power, they had to work to restore order. This was accomplished by an intense focus on the implications of government legislation on social order and stability. Many of their later statutes dealt with forgery; a crime that had, prior to 1700 , been relatively unknown and generally prosecuted as a misdemeanour. Forgery as a prosecuted crime had not appeared in any court records until 1563, when a statute was created that was determined to "protect legal records and documents concerned with the ownership and transfer of land..." There were two main reasons for the increased focus on forgery under the Hanoverians: first it was a crime that was considered serious but that had no real definition under the law; second, the shift in centralization of government power and the appearance of a public, paper based monetary system meant that forgery was both easier to commit and harder to detect. ${ }^{5}$ This revolution was a dramatic improvement on the system of public borrowing of funds that strengthened Britain as a world power and minimized their need to raise funds outside the country. ${ }^{6}$

The financial revolution came to play an important role in the increase of forgery legislation in Britain. During the financial revolution, the increasing privatization of the economy and the introduction of paper notes as means of payment or credit meant that merchants and buyers depended on the honesty of their neighbours. As the opportunities for forgery arose, the output of legislation against the crime also increased. Most of this legislation occurred in the latter part of the eighteenth century; however, its beginnings can be seen at the start of the eighteenth century under George I. The financial revolution occurred rapidly, occurring between 1672 and 1712; forty years transformed England from a country in immense debt under Charles II to one of the strongest economic powers in Europe. It was during this time period that the country experienced a shift from monarchical to parliamentary rule, and the court life began to take a backseat to political ambitions. ${ }^{7}$ Bruce Carruthers argues that this shift in politics was necessary to move the country out of its dependency on tax revenues: "political parties were centrally involved in the establishment of three major joint-stock companies [which] dominated the London stock market...thereby played an important role in public finance." 8 Prior to the Glorious Revolution, Britain's financial system had been reliant on funds and revenue coming from various loan payments, borrowing, and taxes. However, these were not enough to keep up with the constant spending required by the various wars Britain was engaged in, as well as the standard of living maintained by the court. In 1677, when Charles II defaulted on the money he owed to his creditors, the weakness of the British financial system was revealed: "when revenues failed to match expenditures, borrowing was necessary...accumulating deficits soon overwhelmed the public financial system." "The system crashed hard, as the money Charles owed and now had defaulted on was meant to pay back other creditors and patrons of the businesses he had borrowed from. This sent the entire system into a downward spiral compounded by the fact that Parliament refused to grant Charles money to repay the loans.

\footnotetext{
${ }^{4}$ Randall McGowen, "Forgery Legislation in Eighteenth-Century England" in Law, Crime, and English Society 1660-1830, Norma Landau (ed.) (Cambridge, UK: Cambridge University Press, 2002), 122.

${ }^{5}$ McGowen, "From Pillory to Gallows," 133-135.

${ }^{6}$ Bruce G. Carruthers, City of Capital: Politics and Market in the English Financial Revolution (Ewing, NJ: Princeton University Press, 1996), 71.

${ }^{7}$ Hannah Smith, "The Court in England, 1714-1760: A Declining Political Institution?” History 90, no. 297 January 2005): 27-28.

${ }^{8}$ Carruthers, City of Capital, 18.

${ }^{9}$ Ibid., 68.
} 
After the Glorious Revolution, when William of Orange implemented new measures to control taxation and public revenues, and customs were actually generating income, the system was slowly brought under control. William brought Dutch financial advisors to Britain and they worked with the British government to dig the country out of the financial hole it was in and create a system that allowed Britain to, monetarily speaking, rise above other European nations in terms of trade and commerce. Exchequer bills were introduced that served as "short-term, interest bearing bills...circulated much like modern bank notes." 10 These in addition to papers like lottery tickets, investments, and the stock exchanges, led to an increase in use of paper as a means of financial dealings. This became part of the already present credit system, which, according to Craig Muldrew, was "remarkably informal...most...was extended orally in front of witnesses." 11 This was a system that had been in place for many years to facilitate basic survival; the credit system dominated most buying and selling in the economy. This system went hand in hand with debt and thus most people in the sixteenth and seventeenth centuries were owed money and owed money to others. ${ }^{12}$ These dealings in credit were based on the honesty and integrity of the people trading. According to McGowen, trust was a societal function necessary to sustain life in the community; he argues that the financial revolution increased sensitivity to the moral environment and demanded a building up of standards of honesty and credit. ${ }^{13} \mathrm{~J}$. A. Sharpe argues that this development of commerce brought more attention to forgery; people realized that criminal activity could increase as changes occurred in both political and economic spheres. ${ }^{14}$ The problem was that there was not only a shift to a paper based monetary system; there was also a shift from public economics to privatized business. Merchants and businessmen could control certain areas of commerce, rather than everything being available to the public at a fixed rate all the time. These private business owners also had dealings with banks and money, and were exposed to the possibility of forgery more often. The implications that such a fast changing economy would have on the stability of social order and crime were not immediately realized, especially not concerning the crime of forgery. These implications finally became clear in 1728, when the William Hales case created headlines all around Europe.

In 1728, Hales was a bankrupt goldsmith from a well-connected family. He was believed to be an upstanding man whom people trusted and listened to. However, in January 1729, Hales was indicted for "forging and counterfeiting an Indorsment on a forg' $d$ and counterfeit Note." 15 The indictment created outrage among his peers as they realized the implications of his crime on their own personal situations. Hales used the new system of paper money to his advantage, forging important signatures on blank promissory notes and using his connections in the business world to access signatures and thus obtain funds he would not otherwise have had. This trial brought to light the problems that had arisen because of the Financial Revolution and the use of paper to pay off or obtain loans. There were two problems with the system: on one hand, every transaction was based on familiarity. The bankers knew the signatures and the reliability of the businessmen they worked with. On the other hand, there was an increase in the use of anonymous agents to carry out the business themselves; businessmen often entrusted the work to servants or clerks. ${ }^{16}$ The system allowed for easy

\footnotetext{
10 Ibid., 79.

${ }^{11}$ Craig Muldrew, Economy of Obligation: The culture of credit and Social Relations in Early Modern England (New York: Palgrave Macmillan, 1998), 96.

12 Ibid., 97.

${ }^{13}$ McGowen, "From Pillory to Gallows," 134.

${ }_{15}^{14} \mathrm{~J}$. A Sharpe, Crime in Early Modern England 1550-1750 (2 ${ }^{\text {nd }}$ ed.) (London: Longman, 1990), 253.

15 Old Bailey Proceedings Online (accessed March 12, 2011), January 1729, trial of William Hales (t17290116-33).

${ }^{16}$ McGowen, "From Pillory to Gallows," 118-119.
} 
identification for transactions, but made forgery easy to commit if one had the right connections and appeared to be an upstanding, trustworthy citizen. Dishonest servants or desperate friends had more opportunity to forge notes and use the money for personal gains, and the bankers could not know for sure if the agent was trustworthy or not. Signatures only meant endorsement of the order; they did not mean that the order was exactly as the merchant desired. It was not long after this that the first of many forgery statutes were passed by the government, becoming a part of what is now known as the 'bloody code'.

The 'bloody code' was a massive outpouring of legislation in British history; during a forty-eight year period (1712-1760), 3529 statutes were passed. ${ }^{17}$ Much of this legislation seemed to promote capital punishment. Every person who was tried in court stood in danger of the gallows because so many crimes were deemed capital offenses. There were the obvious crimes such as treason, murder, and petty treason, but also seemingly lesser crimes like housebreaking, shoplifting, and theft by servants, all of which became capital offences in the eyes of the government. ${ }^{18}$ The fact that these lesser crimes became capital offences implies desperation to restore order; there was heightened anxiety in London in the decades after the civil war and many people felt that criminals were not being prosecuted enough, or that sentences given were too lenient. The government needed to restore order, and believed that they could best do this by prosecuting any and all criminals that were brought to court. ${ }^{19}$ The bloody code left such an imprint on eighteenth-century Britain that reformers who followed viewed the creators as "at the very least... [inattentive] to the dictates of reason; at worse, they stood condemned of basic inhumanity, since they were so ready to sacrifice the lives of the poor..." 20 John Beattie argues that the 'bloody code' was not necessarily meant to promote only capital punishment; on the contrary, evidence seems to indicate that politicians and lawmakers in the late seventeenth and early eighteenth centuries were often looking for ways to avoid felonious convictions and the death penalty. Often, those who were sentenced to death were given some kind of pardon; transportation and hard labour came to replace the gallows as a felony punishment in many offenses. ${ }^{21}$ However, the people often demanded harsh punishment of every crime, and this was extremely influential in the decisions made by parliamentarians and lawmakers. As a result, many of the proposed measures that would have encouraged lenience in the courts were dismissed. $^{22}$

The place that forgery holds in the bloody code is somewhat unique especially since, as has been mentioned, the crime was virtually unprosecuted until Elizabethan times. After the Elizabethan statute of 1563, the most severe punishment that could be received was imprisonment or standing in the pillory. Even when the first forgery statutes were published during the reign of William of Orange, the laws dealt mostly with public wealth; taxes, revenues, and commercial forgery. These crimes were rarely prosecuted; McGowen points out that "most paper instruments continued to be treated as distinct from the public paper...,"23 by which he means that even though parliament was trying to prevent forgery by creating massive amounts of legislation, their legislation dealt mostly with crimes against the state, rather than the crimes that took place in the private sector. This did

\footnotetext{
17 Sharpe, Crime in Early Modern England, 212.

18 Beattie, John "London Crime and the Making of the 'Bloody Code' 1689-1718" in Stilling the Grumbling Hive (New York: St. Martin’s Press, 1992), 63.

${ }^{19}$ Ibid., 65

${ }^{20}$ Randall McGowen, "Forgery Legislation," 119.

${ }^{21}$ Beattie, "London Crime," 55-56.

22 Ibid, 56.

${ }^{23}$ McGowen, "From Pillory to Gallows," 130.
} 
not change until 1729, when, on May 14, the king approved a new forgery measure drafted by Parliament. Increasingly, forgery was being recognized as dangerous both to private and public paper, as well as to the entire credit system in Britain. The act of 1729 was intended for the private sector; it defined the crime and also determined that anyone who was caught in the act was determined to be guilty without the option of pleading benefit of the clergy. ${ }^{24}$ The new punishment was the gallows, which seemed fitting to the population after the trial of William Hales, and which also fit a new awareness of the crime. ${ }^{25}$ However, McGowen also points out that often those who were pilloried suffered worse than those who were killed. Those in the pillory were shunned by their communities as dishonest and untrustworthy, and so they were often avoided. In a time when social connections meant survival, to be shunned by the community was devastating. ${ }^{26}$

One interesting note here is that, with the increase in legislation against the crime, one would expect to see more trials of forgery that ended in guilty sentences. It would seem that more people, once they knew what the crime entailed, would have noticed anomalies in their business transactions that could indicate forgery. However, this was not the case. In fact, more cases were tried and given guilty sentences at the London Old Bailey prior to the Act of 1729 than after. From 1700-1740, 69 forgery cases tried at the London Old Bailey were given a verdict of guilty, and 20 of these were given the death penalty. Between 1700 and 1729, 56 of the forgery cases tried at the Old Bailey were given a guilty verdict, and 26 were acquitted. Between 1729 and 1740, only 22 cases were judged as guilty and 26 were acquitted. This means that while people were willing to accuse others of forgery, the courts, making use of the new definition, were less inclined or had less opportunity to convict those accused. This disinclination could be part of the notion of mercy, that the courts were afraid the death penalty was too harsh, or it could come back to the simple idea of how to interpret the law. It is possible that while giving a definition of forgery, legislators also narrowed the court's vision; in other words, the courts now had so specific a definition of what constituted forgery that it was harder to convict those accused of the crime.

Showing mercy was something that the courts appear to have engaged in as often as possible to avoid the death penalty. In 1719, John Mills was charged with counterfeiting stamps for papers and instruments, and also with fraud, because he was selling the forged merchandise. It is rare to find a case of multiple charges where the accused was convicted but given a recommendation for mercy, instead of execution. However, in Mills' case, the jury did this because they "did not find any positive Evidence that he knew them to be Counterfeit, tho' they believed in the Conscience from the Circumstances, that he was Guilty." 27 In another case where the death sentence was given, John Hunt was given a recommendation for mercy because he had a wife and 8 children. ${ }^{28}$ Other trials would indicate that the interpretation of the law led to acquittals of the accused; this comes back to the idea that a specific definition of forgery was both necessary and limiting in how the courts determined a verdict. The definition of forgery was too narrow to legitimately prosecute many of the accused, therefore they were acquitted. Many of the acquittals were due to technicalities such as lack of evidence of faults in the indictments. Benjamin Dumbleton was charged in 1717 with counterfeiting a linen stamp. The Old Bailey records only indicated that there was no extended trial and no witness testimony recorded against him; thus the jury acquitted him due to lack of

\footnotetext{
${ }^{24}$ Ibid, 129.

25 Ibid, 135.

${ }^{26}$ Ibid, 123.

${ }^{27}$ Old Bailey Online (accessed March 7), May 1719, trial of John Mills (t-17196514-47).

${ }^{28}$ Old Bailey Online (accessed March 7), June 1720, trial of John Hunt (t-172000602-39).
} 
evidence. $^{29}$ Similar situations occurred with Robert Child in $1716,{ }^{30}$ William Fitch in $1721,{ }^{31}$ and Eleanor Cavernor in $1727 .{ }^{32}$ The lack of evidence recorded in each of these cases could indicate the gaps in knowledge of forgery prior to the strict definition recorded in the act of 1729. In 1729 Thomas Bartlet was indicted for forging a promissory note. The case was dismissed because of a fault in the indictment and was supposed to be tried again in the next Old Bailey Sessions, though there is no record of it. ${ }^{33}$ A similar situation had occurred in years prior; in 1708 Christian Franklin Condrio was acquitted at the Old Bailey because his crime was believed to have been committed in Worcester. ${ }^{34}$ Whether he was tried again is unknown.

The courts could also be influenced based on the social standing of the accused, the witnesses testifying, and the individual who pressed charges. John Styles argues that "the standards of evidence justices were accustomed to meet...were determined by their personal experience, by discussion with colleagues or lawyers and by reference to law books." 35 The judges based their verdicts to some extent on preconceived notions based on what they had read or heard from others. In 1729, right on the heels of the sensational Hales trial, a man named Peter Coffey, charged with forging an endorsement on a promissory note, was acquitted because of a fault in the indictment. However, it appears from records that he was brought back to court in the next Old Bailey session, where he was convicted and given the death penalty. ${ }^{36}$ We know that the man who accused him of forging the note testified against him, as did two merchants who were involved in the transaction concerning the forged note. ${ }^{37}$ These witnesses, being considered of decent social standing and good reputation, would have held considerable sway over the judge's verdict, whereas Coffey, being a man twice indicted, would have been viewed has having questionable character. In addition, Coffey had no person who was willing to testify on behalf of his claimed good character, which left him alone on the witness stand and unable to mount a sustainable defense. In 1733, a man named Edmond Bourk was tried in what appears to be a rather complex case, for forging a promissory note that amounted to $f_{4} 4000$. However, the court deemed that the only evidence against him was circumstantial, and not enough to convict a man for forgery. The charges against him were brought by one Ann Shelly, who claimed he had cheated her out of the money after promising to marry her daughter. However, in his defence, he turned the tables and told the court that he had been warned by neighbours that she was "a cunning old Woman, and bid me take Care of what I did." 38 He had been about to marry her daughter and although the wedding was changed at the last minute, he still received the money he had been promised. There is a possibility that the court's verdict was influenced by the fact that the accuser was a woman, and Bourk's defence against her was sound. In any case, the court was inclined to acquit Bourk of the charges. ${ }^{39}$

However, the cases that were proven guilty after 1729 almost always resulted in the death penalty. Appeals for pardon were normally dismissed because "the judges and the crown...viewed the crime

${ }^{29}$ Old Bailey Online (Accessed March 7,. 2011) January 1717, trial of Benjamin Dumbleton (t-17170111-32).

${ }^{30}$ OBO (accessed March 12, 2011) November 1716, trial of Robert Child (t-17161105-88).

${ }^{31}$ OBO (accessed March 12, 2011) April 1721, trial of William Fitch (t-17210416-25).

32 OBO (accessed March 12, 2011)April 1727 trial of Eleanor Cavernor (t-127270412-49).

33 OBO (accessed March 7, 2011) January 1731, trial of Thomas Bartlet (t-1731011-48).

${ }^{34} \mathrm{OBO}$ (accessed March 7, 2011) July 1708 trial of Christian Franklin Condrio (t-17080707-28).

35 Styles, John "Our traitorous money makers: the Yorkshire Coiners and the Law" in An Ungovernable People, John Brewer (ed.) (New Brunswick: Rutgers University Press, 1980).

${ }^{36}$ OBO (accessed March 7, 2011) October \& December 1729, trials of Peter Coffey, (t-17291015-95, t-17291203-56).

${ }^{37}$ OBO, Peter Coffey (t-17291203-56).

${ }^{38}$ OBO (accessed March 17, 2011) October 1733, trial of Edmond Bourk (t-17331010-21).

${ }^{39}$ OBO, Edmond Bourk (t-17331010-21). 
so seriously." 40 McGowen argues that this view was taken because the crime had serious implications on society; charging and convicting peers of a crime that involved (often) large sums of money undermined societal structure and relationships. In order to avoid setting precedents and giving false hope to the condemned, judges and the crown denied pardons. ${ }^{41}$ So even though the trials were more detailed in their investigations, and there were fewer trials actually brought before the courts for the crime of forgery, those cases that were proven guilty were given the death penalty.

To some extent, the guilty verdict depended on the amount of money being forged. Even before the forgery act of 1729, the amount of money in question often played a role in the decision of the jury. In 1700 , Henry Waldron was tried and convicted in regards to a sum of $£ 300 .^{42}$ In 1716 Thomas Martin was convicted after forging a note for the sum of $£ 120 .^{43}$ After the act of 1729, amounts of money involved still played a role. In 1735, Charles Peel, charged with forging a note for a sum of $£_{1} 170$, was convicted and executed. ${ }^{44}$ In 1738, William Newington was tried for forging an order of payment worth $£ 120$, and was executed in June of that year. ${ }^{45}$ This is important because this was a time period when the economy depended on credit and money to function. Merchants depended on creditors, the monarch depended on loans taken from merchants, and the government was making every effort to control monarchical funds. ${ }^{46}$ When cases involving large sums of money were discovered and charged, those accused were often convicted and executed.

Of the 20 cases that were given the death sentence at the London Old Bailey from 1700-1740, only six occurred prior to 1729. The remaining fourteen were tried afterwards. However, between 1729 and 1740, only 22 out of 49 forgery cases that were tried ended in a guilty verdict. This could indicate several things: the massive outpouring of forgery legislation may have been accomplishing the goal of deterring the crime. The sensation of the Hales trial could have resonated enough to deter other potential forgers in the years following, or the forgers were simply getting better at not getting caught. After the Act, it is true that the majority of guilty cases were given the death sentence. The reason that this seems so high is because many of these guilty verdicts had previously resulted in some kind of corporal punishment, whereas now they resulted in capital punishment. It had been fairly common to see people standing for public punishments, whether that was asking for public forgiveness in the church, standing in the pillory, or locked up in the stocks. Now, public humiliations were less common, and people were gathering more often in London to witness the executions of those deemed guilty of capital offences. This was thought to provide more of a deterrent, as people witnessed public execution as punishment for a crime. However, what the legislators did not take into account in the case of forgery was that many of tried were of an equal standing to those bringing the charges. It was not a matter of accusing a slave or a vagabond of a crime; this was accusing acquaintances and friends of a crime serious enough to be punished with death. This in itself provided a deterrent from reporting and charging people with the crime, as well as from revealing who the criminals actually were. ${ }^{47}$ McGowen points out that social standing at the time was dependent on reputation, and when any hint of scandal appeared, the rumours and

\footnotetext{
${ }^{40}$ McGowen, "From Pillory To Gallows," 137.

41 Ibid., 137.

42 OBO (Accessed March 18, 2011) January 1700, trial of Henry Waldron (t-17000115-28).

${ }^{43}$ OBO (accessed March 18, 2011) January 1716, trial of Thomas Martin (t-17160113-17).

44 OBO (accessed March 18, 2011) May 1735, trial of Charles Peel (t-17350522-3).

${ }^{45}$ OBO (accessed March 18, 2011) June 1738, trial of William Newington (t-17380628-26).

${ }^{46}$ Carruthers, 40.

${ }^{47}$ McGowen, "From Pillory to Gallows," 126-127.
} 
speculation surrounding it could be disastrous for both the accused and the accusers. ${ }^{48}$ No one wanted to be linked with anything that could damage their reputations. Therefore, crimes like forgery went largely unreported.

This lack of reporting of forgery was changed by two sensational trials: the William Hales trial, which highlighted the deficiencies in forgery legislations, and the trial of the Perreau brothers, which solidified the view that forgery was dangerous to social order. The Perreau trial was a complicated one, touching not only on the world of law and justice, but on the greater view of social standing, societal structure, and betrayal of trusts. This case sparked a massive outflow of forgery legislation, because it exposed "the flaws and weaknesses in the operation of justice...law was supposed to get at the truth and serve justice...these goals seemed to recede as the disputes intensified." 49 The point useful here is that sensational trials like those of William Hales and the Perreau brothers brought to light the problems in forgery legislations. Suddenly, people were reporting suspected forgery on a fairly regular basis, and this sparked an outflow of legislation against the crime greater than had ever been seen before.

Forgery at the start of the eighteenth century inspired fear in many people because it posed a threat to every level of social order: political, economic, and social. In a society where everything depended on the state of the economic and financial systems, the idea that someone could be working to undermine those values created a great deal of nervousness in people. Because society had only very recently been embroiled in civil war, and Parliament was fully asserting the powers given it during the Restoration and Glorious Revolution, the need to control crime and society was tremendous. The appearance of forgery legislations and the promotion of crimes from misdemeanour to felony indicate the nervousness of the legislative officials and the measures they took to control criminal activity. Forgery was made a capital crime because it set an example of the consequences of undermining the authority of the government and the government's systems. The fact that the number of cases brought to court dropped after 1729 emphasizes McGowen's point that people did not report the crime often for fear of condemning their friends and neighbours to die on the gallows. ${ }^{50}$ The judges also seem to have found ways to escape convicting accused forgers, thereby allowing the accused to avoid the death sentence. Forgery was a crime that was hard to define, which made it hard to contain. The end result was an all-or-nothing scenario: either you were a forger or you were not, and if you were, you died. Not until the 1770s was this view changed to try and accommodate the different forms of forgery and their different levels of seriousness.

\footnotetext{
48 Ibid., 127.

${ }^{49}$ Donna T. Andrew and Randall McGowen, The Perreaus and Mrs. Rudd (Berkeley: University of California Press, 2001), 188.

50 McGowen, "From Pillory to Gallows," 137.
} 


\section{Bibliography}

Andrew, Donna T. and Randall McGowen. The Perreaus \& Mrs. Rudd: Forgery and Betrayal in Eighteenth-Century London. Berkeley: University of California Press, 2001.

Beattie, John. Policing and Punishment in London 1660-1750: Urban crime and the Limits of Terror. Oxford: Oxford University Press, 2001.

. "London Crime and the Making of the Bloody Code." In Stilling the Grumbling Hive. Lee Davison, Tim Hitchcock, Tim Keirn, et. al. (eds.) New York: St. Martin’s Press, 1992.

Crime and the Courts in England 1660-1800. Ewing, NJ: Princeton University Press, 1986.

Carruthers, Bruce G. City of Capital: Politics and Markets in the English Financial Revolution. Ewing, NJ: Princeton University Press, 1996.

McGowen, Randall. "From Pillory to Gallows: the Punishment of Forgery in the Age of the Financial Revolution." Past Present 165 (Nov. 1999): 175-140.

. "Forgery Legislation in Eighteenth-century England." In Law, Crime, and English Society, 1660-1830. Norma Landau (ed). Cambridge: Cambridge University Press, 2002.

Muldrew, Craig. The Economy of Obligation: the Culture of Credit and Social Relations in Early Modern England. New York: Palgrave Macmillan, 1998.

Old Bailey Proceedings Online (www.oldbaileyonline.org, March 18, 2011) January 1700 trial of Henry Waldron (t-17000115-28).

Old Bailey Proceedings Online (www.oldbaileyonline.org, March 7, 2011) July 1708, trial of Christian Franklin Condrio (t-17080707-28).

Old Bailey Proceedings Online (www.oldbaileyonline.org, March 18, 2011) January 1716 trial of Thomas Martin (t17160113-17).

Old Bailey Proceedings Online (www.oldbaileyonline.org, March 12, 2011) November 1716, trial of Robert Child (t-17161105-88).

Old Bailey Proceedings Online (www.oldbaileyonline.org, March 7, 2011) January 1717, trial of Benjamin Dumbleton (t-17170111-32).

Old Bailey Proceedings Online (www.oldbaileyonline.org, March 7, 2011) May 1719 trial of John Mills (t17196514-47).

Old Bailey Proceedings Online (www.oldbaileyonline.org, March 7, 2011) June 1720 trial of John Hunt (t172000602-39).

Old Bailey Proceedings Online (www.oldbaileyonline.org, March 7, 2011) April 1721, trial of William Fitch (t17210416-25).

Old Bailey Proceedings Online (www.oldbaileyonline.org, March 12, 2011) April 1727 trial of Eleanor Cavernor (t17270412-49).

Old Bailey Proceedings Online (www.oldbaileyonline.org, March 12, 2011) January 1729; trial of William Hales (t17290116-33).

Old Bailey Proceedings Online (www.oldbaileyonline.org, March 7, 2011) October \& December 1729, trials of Peter Coffey (t-17291015-95, t-17291203-56).

Old Bailey Proceedings Online (www.oldbaileyonline.org, March 7, 2011) January 1731, trial of Thomas Bartlet (t1731011-48).

Old Bailey Proceedings Online (www.oldbaileyonline.org, March 17, 2011) October 1733, trial of Edmond Bourke (t-17331010-21). 
Old Bailey Proceedings Online (www.oldbaileyonline.org, March 18, 2011) May 1735 trial of Charles Peel (t17350522-3).

Old Bailey Proceedings Online (www.oldbaileyonline.org, March 18, 2011) June 1738 trial of William Newington (t-17380628-26).

Sharpe, J.A. Crime in Early Modern England 1550-1750 (2nd ed.). London: Longman, 1999.

Smith, Hannah. “The court in England, 1714-1760: a Declining Political Institution?” History 90 (January 2005): 23-41.

Styles, John. "Our traitorous moneymakers: the Yorkshire coiners and the law, 1760-83." In An Ungovernable People: the English and their Law in the Seventeenth and Eighteenth Centuries. John Brewer \&John Styles (eds.) New Brunswick: Rutgers University Press, 1980. 